\title{
STUDY ON VARIATIONS OF SHAPE, SIZE, LOCATION AND POSITION OF MENTAL FORAMEN AND INCIDENCE OF ACCESSORY MENTAL FORAMEN IN HUMAN MANDIBLES
}

\author{
Rajkumari Ajita1, Sanjenbam Sonali Devi², Nirmalendu Das ${ }^{3}$ \\ ${ }^{1}$ Associate Professor, Department of Anatomy, Regional Institute of Medical Sciences, Imphal, Manipur. \\ ${ }^{2}$ Senior Resident, Department of Anatomy, Regional Institute of Medical Sciences, Imphal, Manipur. \\ ${ }^{3}$ Post Graduate Trainee, Department of Anatomy, Regional Institute of Medical Sciences, Imphal, Manipur.
}

\section{ABSTRACT}

\section{AIM AND OBJECTIVE}

The present study was conducted with an objective to determine the size, shape, location, position and number of Mental Foramen (MF) and Accessory Mental Foramen (AMF) on both sides of mandible and incidence of MF and AMF with respect to the surgically encountered important anatomical landmarks and compare with the findings of available literatures.

\section{METHODS AND MATERIALS}

The study was conducted on 50 dry adult human mandibles of unknown sex and age obtained from the Department of Anatomy of Regional Institute of Medical Sciences (RIMS), Imphal, Manipur, India. The shape, size, location and position of MF were measured on both sides of mandible by using Digital Vernier Caliper.

\section{RESULTS}

Mental foramen was present in all 50 mandibles and it was bilateral and the incidence of AMF was observed in only four mandibles (8\%). In the present study, the round shape MF was observed in $17.05 \%$ and the oval shape of MF in $82.95 \%$. Average size of AMF was $1.50 \mathrm{~mm}$ ranging from $1.00 \mathrm{~mm}$ to $2.00 \mathrm{~mm}$. The location of the MF was found mostly below the apex of second premolar in $74.50 \%$, while it was $25.50 \%$ between the first and second premolars.

\section{CONCLUSION}

The knowledge about variations in size, shape, location and position of MF and presence of AMF will help the Dental Surgeons to determine accurate site of local anaesthesia and in avoiding injury to mental nerve and prevent unwanted spread of infections while performing periodontal or endodontic surgery.

\section{KEYWORDS}

Mental Foramen, Accessory Mental Foramen, Mandible, Mental Nerve, Premolar.

HOW TO CITE THIS ARTICLE: Ajita R, Devi SS, Das N. Study on variations of shape, size, location and position of mental foramen and incidence of accessory mental foramen in human mandibles. J Evolution Med Dent Sci 2016;5(1):30-35,

DOI: $10.14260 /$ jemds/2016/8

\section{INTRODUCTION}

The Mental Foramen (MF) is a small foramen which is located in the antero-lateral aspect of the body of the mandible. It is situated midway between the upper and the lower border of the mandible and it transmits mental nerve, artery and vein. ${ }^{[1,2]} \mathrm{MF}$ is an important anatomical landmark to facilitate diagnostic, surgical, local anesthetic and other invasive procedures for Dental Surgeons performing periapical surgery in the mental region of mandible. Normally, MF is located below the interval between the two premolars. ${ }^{[3,4]}$ The mental nerve and vessels emerges through the MF and supply sensory innervation and blood supply to the soft tissues of the chin, lower lip and gingiva.[5,6] Variations of MF are often encountered ranging from difference in shape and positions to presence of Accessory Mental Foramen (AMF) or even complete absence in some cases. ${ }^{[3,7-12]}$

Financial or Other, Competing Interest: None.

Submission 16-12-2015, Peer Review 17-12-2015,

Acceptance 29-12-2015, Published 02-01-2016.

Corresponding Author:

Dr. Rajkumari Ajita,

Pishumthong Oinam Leikai,

Imphal-795001,

Manipur, India.

E-mail: ajitark39@gmail.com

DOI:10.14260/jemds/2016/8
Studying the position and its morphological variations of MF is very important, because it will be helpful to localize the important maxillofacial neurovascular bundle passing through the MF, but the position of MF vary among racial groups and genders. $[3,13-17]$

The most common position of MF is in line with the longitudinal axis of the $2^{\text {nd }}$ pre-molar tooth followed by a location between the $1^{\text {st }}$ and second pre-molar tooth. ${ }^{[13,18]}$ Most of MF are oriented postero-superiorly. Variations in the position of MF have been reported by many authors in different ethnic groups and various shapes have also been noticed. Normally data from various ethnic groups e.g. Tanzanian, Thai, Chinese, British, Saudi Arabian vary regarding the location of MF. Knowing the variation of MF location is important for locational blockage of the incisor nerve in periapical surgeries involving molars and premolars and bucco-maxillofacial surgical procedures.[1,17-22]

Any foramen which is in addition to MF is considered as an Accessory Mental Foramen (AMF) and it is usually located below the $1^{\text {st }}$ molar tooth. $[17,23,24,25]$ Ethnic variations in relation to AMF have also been reported by Sawyer et al.[9] This AMF may transmit the branches of the mental nerve. AMF is due to the branching of mental nerve before passing through MF. The study of the incidence of AMF will help to localize the important neuromuscular bundle passing through MF.[26] 
Hence, the location, size, shape, position and incidence of MF and AMF would facilitate the Dental Surgeons to apply nerve block in different surgical procedures involving lower jaw and to achieve complete anaesthesia and also helpful to avoid injury during periapical surgery.[27]

Gary Greenstein et al.[28] in their study reported that injuries to mental nerve during implant placement can be avoided if MF is located and evaluated and this information is used to help guide surgical procedures. Precise knowledge on variations in the position, shape and the size of MF and the presence of AMF would be of great use for Dental Surgeons while performing surgical procedures on the mandible, such as curettage of premolars, filling procedures, dental implants, root canal treatments, orthognathic surgeries etc. ${ }^{[4,20]}$

Despite the fact that many studies have been conducted on the subject matter by various workers, the relevant data and findings available are still considered inadequate. Hence, this present study was conducted with an objective to investigate the shape, size, location and position of MF and incidence of AMF with respect to the surgically encountered important anatomical landmarks and compare with the findings of available literatures.

\section{METHODS AND MATERIALS}

Our study was conducted on 50 dry adult human mandibles of unknown sex and age obtained from the Department of Anatomy of Regional Institute of Medical Sciences (RIMS), Imphal, Manipur, India and the study was carried out to determine the size, shape, location, position and number of MF and AMF on both sides of mandible. The shape, size, location, position and number of MF were measured on both sides of mandible by using Digital Vernier Caliper. Mean horizontal and vertical diameters were measured by using Digital Vernier Caliper. The shape of MF observed was either oval or round. Position of MF was identified by measuring the distance from (a) Symphysis menti, (b) Inferior border of the mandible, (c) Posterior border of the ramus and (d) Superior border of the body of the mandible to MF. The position of MF was noted in relation to mandibular teeth.

\section{RESULTS AND DISCUSSION}

Mental foramen was present in all 50 (fifty) mandibles under study and it was bilateral. In the present study, AMF was noted in four mandibles, two on the left side (4\%) and another two (4\%) on the right side. That is, the incidence of occurrence of AMF was $8 \%$. None of the mandibles presented with bilateral AMF. In our present study, we observed that the round shape MF was observed in $17.05 \%$ and the oval shape of MF in $82.95 \%$. MF was located mostly below the $2^{\text {nd }}$ premolar followed by the location between $1^{\text {st }}$ and $2^{\text {nd }}$ premolar. Mesbahul $\mathrm{H}$ et al.[17] reported that no MF was found between $2^{\text {nd }}$ premolar and $1^{\text {st }}$ molar. In conformity with this finding, Hasan T reported that MF was found under the root of the second premolar in most mandibles.[11] The most common location of MF at the root of the $2^{\text {nd }}$ premolar teeth might be due to racial variations and researchers' observational error.[17]

As pointed out above, only 4(Four) mandibles were found to have AMF out of 50 mandibles studied. Average size of $A M F$ was $1.50 \mathrm{~mm}$ ranging from $1.00 \mathrm{~mm}$ to $2.00 \mathrm{~mm}$, thereby showing that AMF was smaller in size than the regular MF. In the present study, the location of MF was found mostly below the apex of second premolar in $74.50 \%$, while it was $25.50 \%$ between the first and second premolars. However, no mandibles was found having its location between second premolar and first molar.

Whereas, in one study conducted by Vimala $V$ et al.[27] it was observed that the most frequent position of MF was in line with apex of $2^{\text {nd }}$ premolar $(61.4 \%)$ and the second common position was between $2^{\text {nd }}$ premolar and $1^{\text {st }}$ molar $(28.2 \%)$, the finding of which was found slightly different from our study. According to standard text books, MF is most commonly situated between the apices of the first and second lower premolar.[3,5] In the present study, it was found mostly below second premolar $(74.50 \%)$, which is not in conformity with that of Sinnthamby. ${ }^{[5]}$ Racial variation in the position of MF is clearly demonstrated. The modal position of MF in Chinese was in line with the second premolar, whereas in Britishers it was between the first and second premolars. [7]

Some samples of the mandibles showing the location, size, shape and position of MF and AMF studied in the present study are shown below

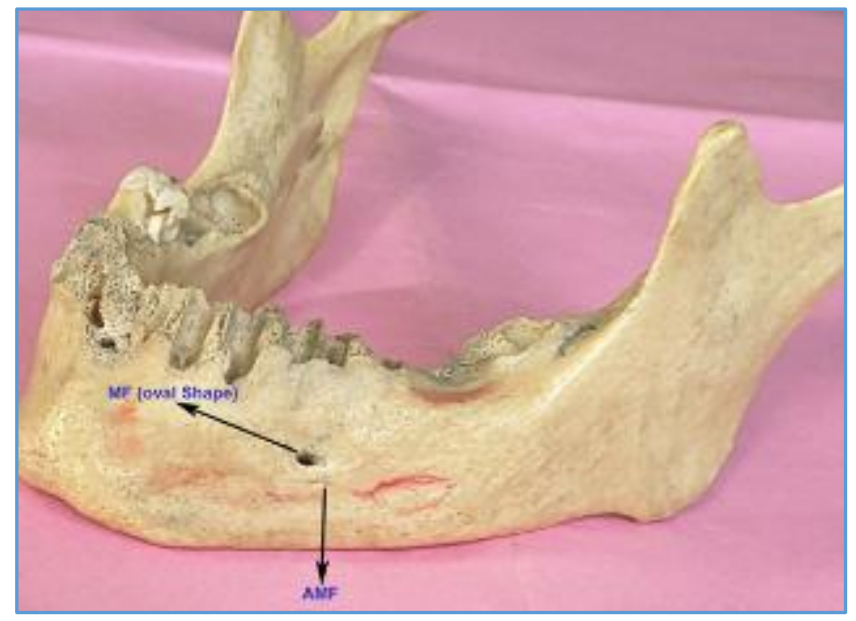

Fig. 1: Mandible showing the location of Mental Foramen (MF) of oval shape below the $2^{\text {nd }}$ premolar and presence of Accessory Mental Foramen (AMF) as well below MF

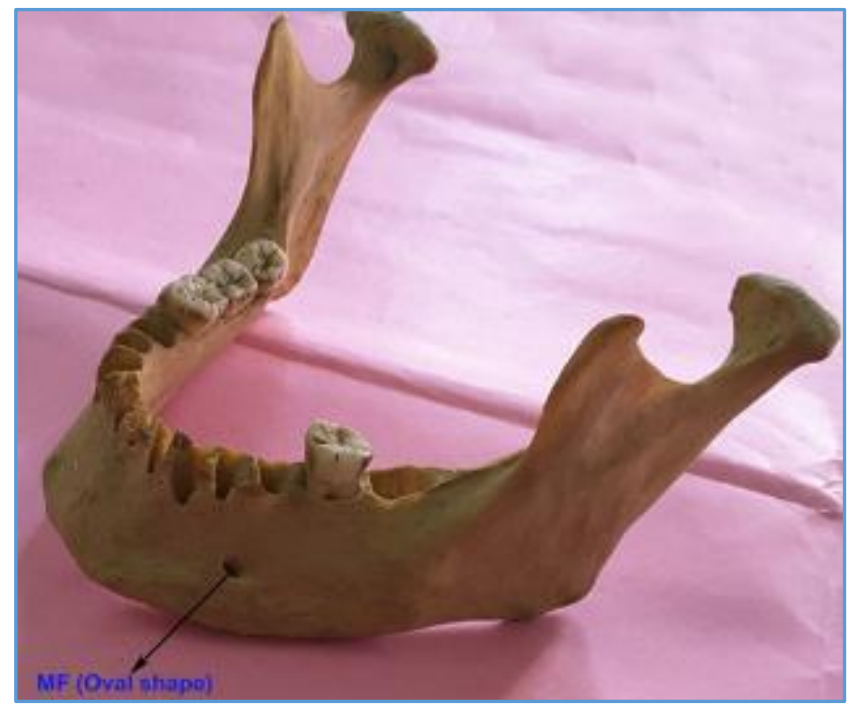

Fig. 2: Mandible showing the location of Mental Foramen (MF) of oval shape lying between the $1^{\text {st }}$ and $2^{\text {nd }}$ premolar 


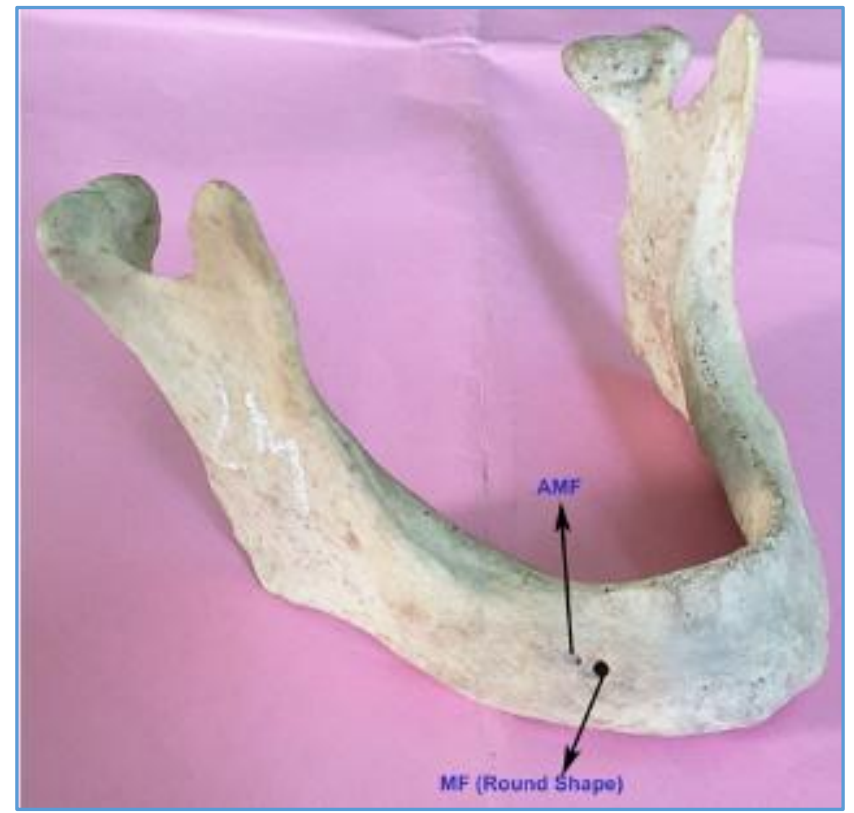

Fig. 3: Mandible showing the presence of both Mental Foramen (MF) of round shape as well as Accessory Mental Foramen (AMF) on the right side

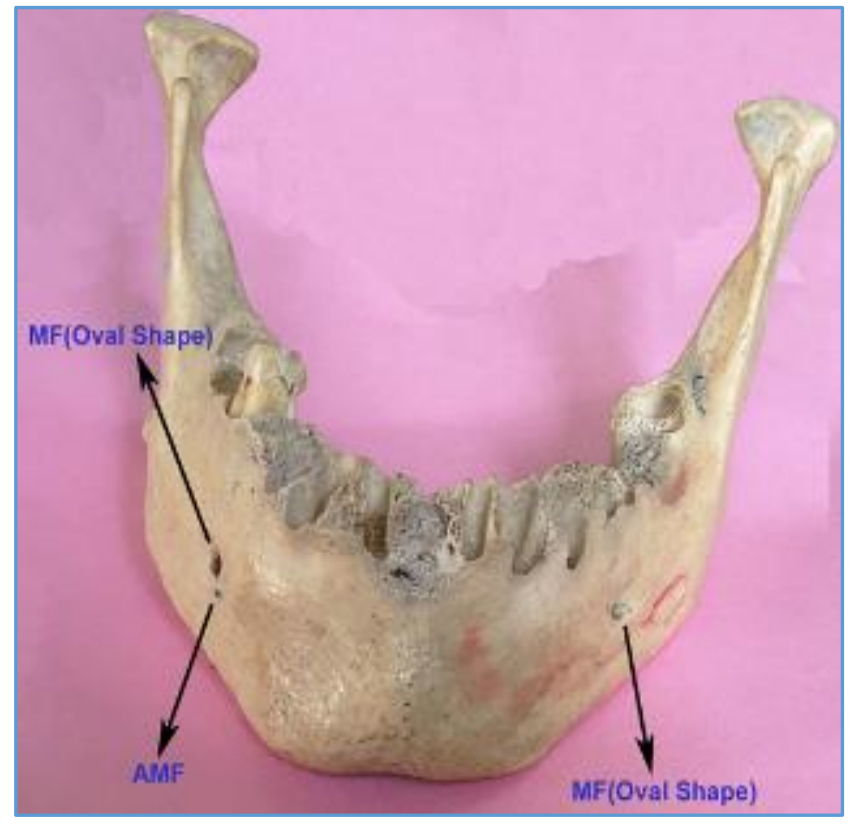

Fig. 4: Mandible showing the presence of Mental Foramen (MF) of oval shape on both the right and left sides as well as presence of Accessory Mental Foramen (AMF) on the right side

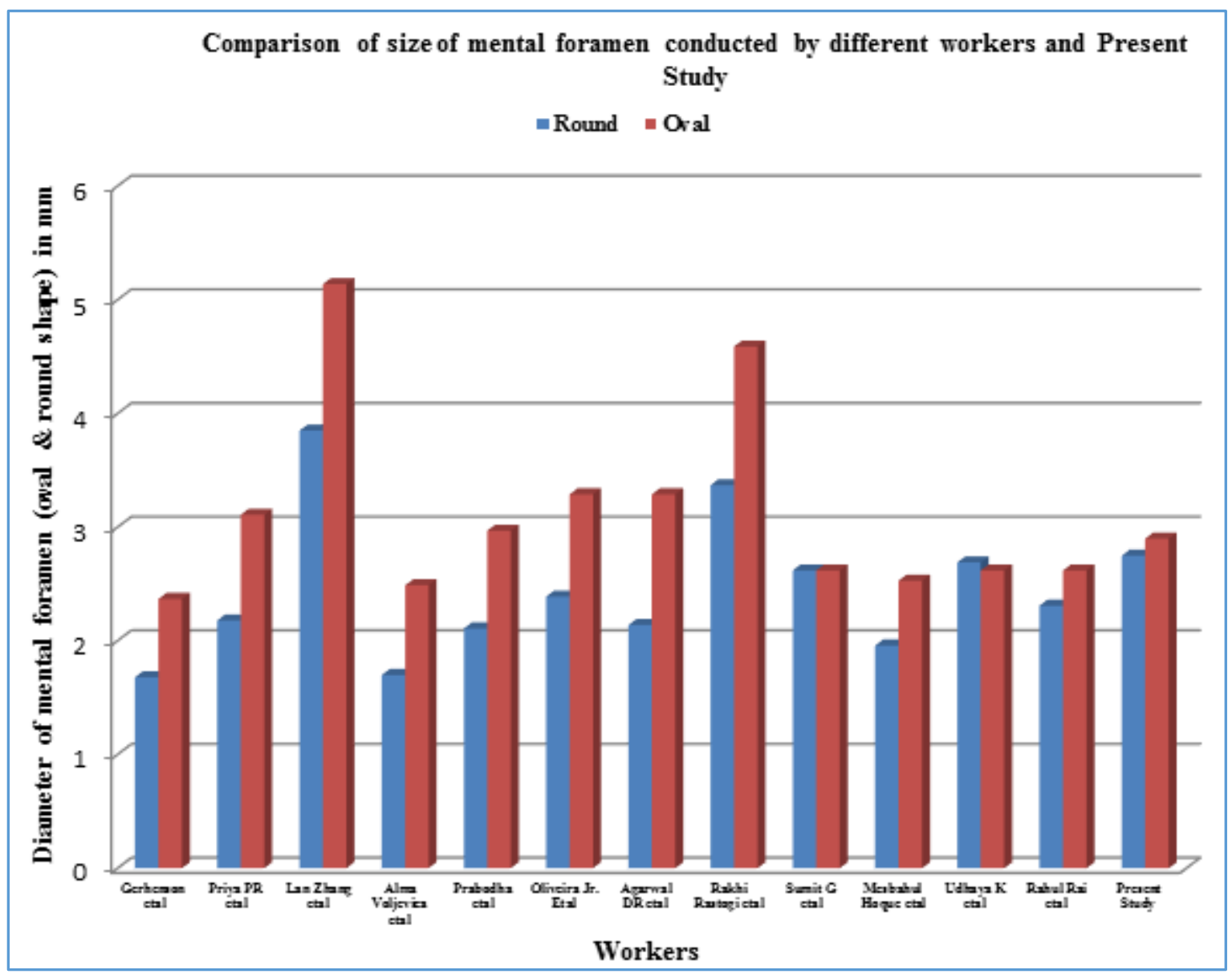

Fig.5: Bar Diagram showing the comparison of size of Mental Foramen of Mandibles conducted by different workers with that of the present study

As can be seen from Fig. 5, it could be observed that the mean diameter size of oval shape MF of our study was found almost similar to the findings of Prabodha et al.[13] and Priya PR et al.[29] and very close to that of Rahul Rai et al.[30] Udhaya K et al.[1], Mesbahul H et al..[17], Sumit G et al.[31] Alma Voljevica et al.[20] and Gerhenson A et al..[32] whereas in the case of round shape it was found closer to the findings of Udhaya K et al.[1] Sumit G et al..[31] and Oliveira Junior et al.[19] 


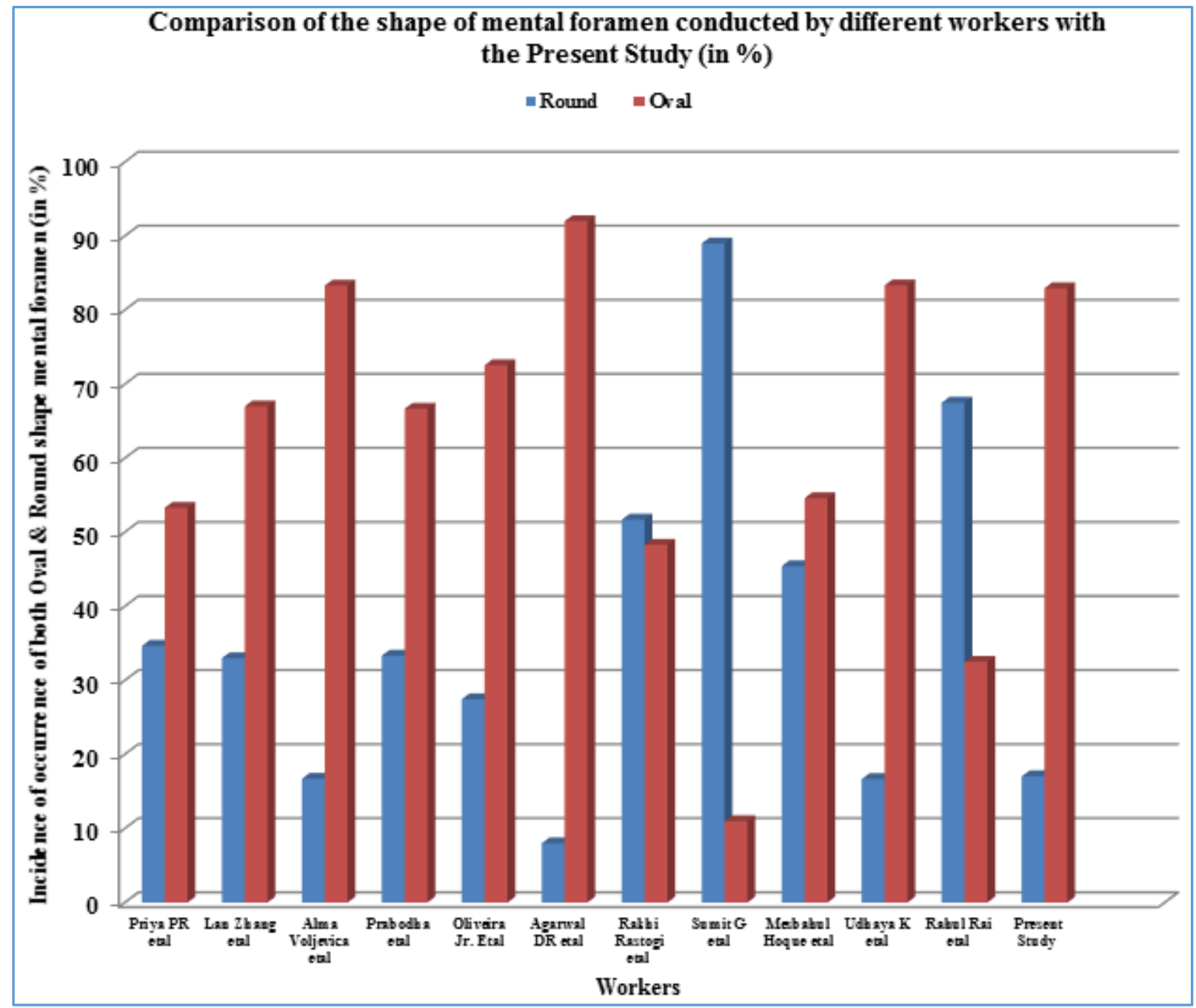

Fig.6: Bar Diagram showing the comparison of shape of Mental Foramen of Mandibles conducted by different workers with that of the present study

As regards the shapes of MF reported by different workers, the above Bar Diagram showed that the occurrence of both oval and round shape MF in our study was found almost in conformity with the findings of Udhaya K et al.[1] and Alma Voljevica et al.[20]

\begin{tabular}{|c|c|c|c|c|}
\hline $\begin{array}{l}\text { Sl. } \\
\text { No. }\end{array}$ & Authors & $\begin{array}{c}\text { No. of } \\
\text { Mandibles }\end{array}$ & $\begin{array}{l}\text { No. of } \\
\text { AMF }\end{array}$ & $\begin{array}{c}\% \text { of } \\
\text { Occurrence }\end{array}$ \\
\hline 1 & Prabodha LBL et al. (2006).[13] & 24 & 2 & 8.33 \\
\hline 2 & Naitoh M et al. (2009).[33] & 157 & 11 & 7.00 \\
\hline 3 & Sumit G et al. (Mar, 2012).[31] & 120 & 8 & 6.67 \\
\hline 4 & Udhaya K et al. (Aug, 2013).[1] & 90 & 5 & 5.56 \\
\hline 5 & Virendra B et al. (2013).[6] & 105 & 7 & 6.60 \\
\hline 6 & Vimala V et al. (Sept, 2015).[27] & 35 & 2 & 5.71 \\
\hline 7 & Alma Voljevica et al. (2015).[20] & 150 & 4 & 2.67 \\
\hline 8 & Shukla RK et al. (2015).[34] & 70 & 5 & 7.20 \\
\hline 9 & Zhang L et al. (2015).[35] & 172 & 10 & 5.81 \\
\hline 10 & Present Study & 50 & 4 & 8.00 \\
\hline
\end{tabular}

The incidence of AMF varies in the literature. ${ }^{[6]}$ Singh $\mathrm{R}$ and Srivastav AK observed AMF in $13 \%$ mandibles. ${ }^{[4]}$ However, the incidence of AMF was reported to be only $2.70 \%$ by Serman. ${ }^{[36]}$ In the study conducted by Virendra B et al.[6] the incidence of AMF was found $6.6 \%$. AMF was found in $5.81 \%$ in the study conducted by Zhang $\mathrm{L}$ et al.[35] As can be seen from the above Table-I, it could be ascertained that the incidence of occurrence of AMF as reported by various workers was found ranging from $2.67 \%$ to $8.33 \%$, with the finding in the present study (8\%) very close to the findings of Prabodha et al.[13] 


\begin{tabular}{|c|c|c|c|c|c|c|}
\hline \multirow{2}{*}{$\begin{array}{l}\text { Sl. } \\
\text { No. }\end{array}$} & \multirow[t]{2}{*}{ Authors } & \multirow{2}{*}{$\begin{array}{c}\text { No. of } \\
\text { Mandibles }\end{array}$} & \multicolumn{2}{|c|}{$\begin{array}{c}\text { Size of MF } \\
\text { (Mean diameter in } \mathbf{m m} \text { ) }\end{array}$} & \multicolumn{2}{|c|}{$\begin{array}{c}\text { Shape of } \\
\text { Mental Foramen (\%) }\end{array}$} \\
\hline & & & Round & Oval & Round & Oval \\
\hline 1 & Gerhenson A et al. (1986).[32] & 575 & 1.68 & 2.37 & 34.50 & 65.50 \\
\hline 2 & Priya PR et al. (2014).[29] & 75 & 2.18 & 3.11 & 34.67 & 53.30 \\
\hline 3 & Zhang L et al. (2015).[35] & 172 & 3.85 & 5.14 & 33.00 & 67.00 \\
\hline 4 & Alma Voljevica et al. (2015).[20] & 150 & 1.70 & 2.49 & 16.70 & 83.30 \\
\hline 5 & Prabodha LBL et al. (2006).[13] & 24 & 2.11 & 2.97 & 33.33 & 66.67 \\
\hline 6 & Oliveira Jr. et al. (2009) ${ }^{[19]}$ & 80 & 2.39 & 3.29 & 27.45 & 72.55 \\
\hline 7 & Agarwal DR et al. (Jan 2011).[3] & 100 & 2.14 & 3.29 & 8.00 & 92.00 \\
\hline 8 & Rakhi R et al. (2012).[37] & 87 & 3.37 & 4.59 & 51.70 & 48.30 \\
\hline 9 & Sumit G et al. (2012).[31] & 120 & $\begin{array}{c}2.62 \\
\text { (Av. Size) }\end{array}$ & $\begin{array}{c}2.62 \\
\text { (Av. Size) }\end{array}$ & 89.00 & 11.00 \\
\hline 10 & Mesbahul H et al. (Jan, 2013).[17] & 185 & 1.96 & 2.53 & 45.41 & 54.59 \\
\hline 11 & Udhaya K et al. (Aug 2013).[1] & 90 & 2.69 & 2.62 & 16.67 & 83.33 \\
\hline 12 & Rahul Rai et al. (Jul 2014).[30] & 40 & 2.31 & 2.62 & 67.50 & 32.50 \\
\hline 13 & Present study) & 50 & 2.75 & 2.90 & 17.05 & 82.95 \\
\hline
\end{tabular}

\begin{tabular}{|c|c|c|c|c|c|c|c|c|c|c|}
\hline \multirow[b]{2}{*}{$\begin{array}{l}\text { Sl. } \\
\text { No. }\end{array}$} & \multirow[b]{2}{*}{$\begin{array}{c}\text { Mean } \\
\text { distance } \\
\text { from } \\
\text { (in } \mathbf{m m} \text { ) }\end{array}$} & \multicolumn{8}{|c|}{ Authors } & \multirow[b]{2}{*}{$\begin{array}{l}\text { Present } \\
\text { Study }\end{array}$} \\
\hline & & $\begin{array}{c}\text { Wang } \\
\text { TM et al. } \\
\text { (1986) } \\
{[23]}\end{array}$ & $\begin{array}{l}\text { Prabodha } \\
\text { et al. } \\
(2006)^{[13]}\end{array}$ & $\begin{array}{c}\text { Sumit G } \\
\text { et al. } \\
(2012) \\
{[31]}\end{array}$ & $\begin{array}{c}\text { Vimala } \\
\text { V et al. } \\
(2015) \\
{[27]}\end{array}$ & $\begin{array}{l}\text { Singh R et } \\
\text { al. } \\
(2010)^{[4]}\end{array}$ & $\begin{array}{l}\text { Apinhasmit } \\
\text { W et al. } \\
(2006)^{[38]}\end{array}$ & $\begin{array}{c}\text { Alma } \\
\text { Voljevica } \\
\text { et al. } \\
\text { (2015) }\end{array}$ & $\begin{array}{l}\text { Agarwal } \\
\text { DR et al. } \\
\text { (2011) }\end{array}$ & \\
\hline 1 & $\begin{array}{c}\text { Symphysis } \\
\text { menti }\end{array}$ & 28.06 & 26.52 & 29.12 & 26.67 & 29.95 & 28.83 & 25.63 & 25.30 & 25.90 \\
\hline 2 & $\begin{array}{c}\text { Posterior } \\
\text { border } \\
\text { of the } \\
\text { ramus }\end{array}$ & 74.14 & 65.58 & 74.16 & 62.35 & 78.25 & 68.85 & 59.01 & - & 62.50 \\
\hline 3 & $\begin{array}{c}\text { Inferior } \\
\text { border } \\
\text { of the body }\end{array}$ & 14.70 & 12.25 & 14.45 & 11.25 & 15.50 & 14.88 & 12.70 & 12.14 & 12.95 \\
\hline 4 & $\begin{array}{c}\text { Alveolar } \\
\text { crest }\end{array}$ & - & - & - & - & 17.80 & - & 14.37 & 13.94 & 13.13 \\
\hline
\end{tabular}

In the present study, the position of MF from various parameters i.e. mean distance from symphysis menti, posterior border of the ramus, inferior border of the body and Alveolar crest was observed at $25.90 \mathrm{~mm}, 62.50 \mathrm{~mm}, 12.95 \mathrm{~mm}$ and $13.13 \mathrm{~mm}$ respectively, as can be seen from the Table-III shown above. The findings of the present study was found almost similar and in close conformity with the findings of the studies conducted by Prabodha et al.[13] Vimala V et al..[27] Alma Voljevica et al.[20] and Agarwal DR et al. [3]

The limitation of the present study is that there is every possibility that the workers might have committed some inadvertent mistakes while measuring various parameters, despite maximum care and precaution taken by the authors, even though the measurement was carried out using Digital Vernier Calipers. Another limitation is the limited availability of dry human mandibles (50 numbers only).

\section{CONCLUSION}

The present study revealed variations in shape, size, location and position of MF and incidence of occurrence of AMF. Prior knowledge about variations in size, shape, location and position of MF and presence of AMF will help the Dental Surgeons and Anatomists alike to achieve full anaesthesia after nerve block. The findings of our study will be of great help to Dental Surgeons for determining accurate site of local anaesthesia and in avoiding injury to mental nerve and prevent unwanted spread of infections while performing periodontal or endodontic surgery. Further research in the field with significantly larger numbers of mandibles will definitely bring interesting and useful findings.

\section{ACKNOWLEDGEMENT}

The authors express their special thanks to Shri T. Ranjit Singh for computer typing of this original article.

\section{REFERENCES}

1. Udhaya K, Saraladevi KV and Sridhar J. The Morphometric Analysis of the Mental Foramen in Adult Dry Human Mandibles: A Study on the South Indian Population. Journal of Clinical and Diagnostic Research 2013 Aug; 7(8):15471551.

2. Igbigbi PS and Lebona S. The position and dimensions of the mental foramen in adult Malawian mandibles. West African Journal of Medicine 2005;24:184-89.

3. Agarwal DR and Gupta SB. Morphometric analysis of mental foramen in human mandibles of South Gujarat. People's Journal of Scientific Research 2011;4(1):15-18.

4. Singh R and Srivastav AK. Study of position, shape, size and incidence of mental foramen and accessory mental foramen in Indian adult human skulls. Int J Morphol 2010;28(4):1141-1146.

5. Sinnathamby CS. Last's Anatomy: Regional and Applied. $10^{\text {th }}$ Edn.; Churchill Livingstone, Edinburgh. 1999;506. 
6. Virendra B, Rakhi R, Rekha L, et al. Study of position, shape and size of mental foramen utilizing various parameters in dry adult human mandibles from North India. Hindawi Publishing Corporation ISRN Anatomy Volume 2013, Article ID 961429, 5 pages,

http://dx.doi.org/10.5402/2013/961429.

7. Santini A and Land M. A comparison of the position of mental foramen in Chinese and British mandibles. Acta Anat (Basel) 1990;137:208-212.

8. Zivanović S. Some morphological characters of the East African Mandible. Acta Anatomica 1970;77(1):109-119.

9. Sawyer DR, Kiely ML and Pyle MA. The frequency of accessory mental foramina in four ethnic groups. Archives of Oral Biology, 1998;43(5):417-420.

10. Defreitas V, Mdeira MC, Tsledofilhs JL, et al. Absence of the mental foramen in dry human mandible. Acta Anatomica, 1979;104(3):353-355.

11. Hasan T. Characteristics of the mental foramen in different populations. The Internet Journal of Biological Anthropology, 2010;4(2):1-7.

12. Agthong S, Huanmanop T and Chentanez V. Anatomical variations of the supraorbital, infraorbital and mental foramina related to gender and side. Journal of Oral and Maxillofacial Surgery, 2005;63(6):800-804.

13. Prabodra LBL and Nanayakkara BG. The position, dimension and morphological variations of mental foramen in mandibles. Galle Medical Journal, 2006;11(1):13-15.

14. Cutright B, Quillopa N and Schubert W. An anthropometric analysis of the key foramina for maxillofacial surgery. Journal of Oral and Maxillofacial Surgery, 2003;61(3):354357.

15. Defreitas V, Madeira MC, Pinto CT, et al. Direction of the mental canal in human mandibles. Aust Dent J 1979;21(4):338-340.

16. Green RM. The position of the mental foramen: a comparison between the southern (Hong Kong) Chinese and other ethnic and racial groups. Oral Surgery, Oral Medicine, Oral Pathology, 1987;63(3):287-290.

17. Md Mesbahul H, Shamim A, Shahanaz Begum, et al. Study of number, shape, size and position of mental foramen in Bangladeshi Dry Adult Human Mandible. Bangladesh J Anat 2013;11(1):7-10.

18. Mbajiorgu FE, Zivanovic S, Asala SA, et al. A pilot study of the mandibular angle in black Zimbabweans. Cent Afr J med 1996;42(10):285-287.

19. Oliveira JEM, Araujo ALD, Dasilva CMF, et al. Morphological and morphometric study of the mental foramen on the MCP- 18 Jiachenjiang point. Int J Morphol 2009;27(1):231238.

20. Alma Voljevica, Elvira Talovic and Aida Hasanovic. Morphological and morphometric analysis of the shape, position, number and size of mental foramen on human mandibles. Acta Medica Academica 2015;44:31-38.

21. Singh R and Srivastav AK. Evaluation of position, shape, size and incidence of mental foramen and accessory mental foramen in Indian adult human skulls. International Journal of Exp and clinical Anat, 2011 April; p.1-7.
22. Lopes PTC, Pereira GAM and Santos AMPV. Location of the mental foramen in dry mandibles of adult individuals in Southern Brazil. J Morphol Sci 2010;27(1):23-25.

23. Wang TM, Shih C, Liu JC, et al. A clinical and anatomical study of the location of the mental foramen in adult Chinese mandibles. Acta Anat 1986;126(1):29-33.

24. Oguz $O$ and Bozkir MG. Evaluation of location of mandibular and mental foramina in dry, young, adult human male, dentulous mandibles. West Indian Med J 2002;51:14-16.

25. Cagirankaya LB and Kansu H. An accessory mental foramen: a case report. J Contemp Dent Pract, 2008;9:98104.

26. Nandakumar and Thenmozhi. A study of incidence of accessory mental foramen in South Indian mandibles. J Pharm Sci and Res 2015;7(7):445-447.

27. Vimala V, Rohinidevi M and Mekala D. Study of anatomical variations of mental foramen in Dry Adult human mandibles and its clinical importance. IOSR Journal of Dental and Medical Sciences Ver V Sep 2015;14(9):40-44.

28. Gary Greenstein and Dennis Tarnow. The mental foramen and nerve: Clinical and Anatomical factors related to dental implant placememt: A literature review. J Periodontol 2006;77:1933-1943.

29. Priya PR, Ambali MP, Doshi MA, et al. Variation in the position and shape and direction of mental foramen in dry mandible. Int J Anat Res 2014;2(2):418-420.

30. Rahul Rai, Shailaza Shrestha and Sudha Jha. Mental Foramen: a morphological and morphometrical study. International J of Healthcare and Biomedical Research, July 2014;2(4):144-150.

31. Sumit G and Jagdish SS. Study of anatomical variations and incidence of mental foramen and accessory mental foramen in dry human mandibles. National Journal of Medical Research 2012(Mar);2(1):28-30.

32. Gershenson A, Nathan H and Luchansky E. Mental foramen and mental nerve: changes with age. Acta Anatomica 1986;126(1):21-28.

33. Naitoh M, Hiraiwa Y, Aimiya H, et al. Accessory mental foramen assessment using cone-beam computed tomography. Oral Surg Oral Med Oral Pathol. Oral Radiol Endod 2009;107(2):289-294.

34. Shukla RK, Gupta P, Hussein M, et al. Morphometric measurement of Mental Foramen in dry human mandible in North Indian population. Int J Anat Res 2015;3(1):899905.

35. Zhang L, Zheng Q, Zhou X, et al. (2015). Anatomic relationship between Mental Foramen and Peripheral Structures observed by one-Beam Computed Tomography. Anat Physiol 5:182.doi:10.4172/2161-0940.1000182.

36. Serman NJ. The mandibular incisive foramen. Journal of Anatomy, 1989;167:195-198.

37. Rakhi R, Virendra B, Sathpathi DK, Sandeep Singh, Kranti Kumar Gour and Shema Nair. Morphology and morphometry of the mental foramen in dry adult human mandibles from central India and their clinical correlation Eur J Anat 2012;16(1):22-26.

38. Apinhasmit W, Methathrathip D, Chompoopong S, et al. Mental foramen in Thais: an anatomical variation-lated to gender and side. Surg Radiol Anat 2006;28:529-533. 